\title{
Process Analysis as a Feedback Tool for Development of Engineering Prob- lem Solving Skills
}

\author{
Dr. Sarah Jane Grigg, Clemson University \\ Mrs. Jennifer Van Dyken, Clemson University \\ Dr. Lisa Benson, Clemson University
}

Lisa Benson is an Associate Professor in the Department of Engineering and Science Education at Clemson University, with a joint appointment in the Department of Bioengineering. Dr. Benson teaches first year engineering, undergraduate research methods, and graduate engineering education courses. Her research interests include student-centered active learning, assessment of motivation, and how motivation affects student learning. She is also involved in projects that utilize Tablet PCs to enhance and assess learning, and incorporating engineering into secondary science and math classrooms. Her education includes a B.S. in Bioengineering from the University of Vermont, and M.S. and Ph.D. degrees in Bioengineering from Clemson University.

\section{Dr. Beshoy Morkos}

Beshoy Morkos is a newly appointed assistant professor in Mechanical and Aerospace Engineering at the Florida Institute of Technology. Dr. Morkos was a postdoctoral researcher in the Department of Engineering \& Science Education at Clemson University performing NSF funded research on engineering student motivation and its effects on persistence and the use of advanced technology in engineering classroom environments. Dr. Morkos received his Ph.D. from Clemson University in the Clemson Engineering Design and Applications Research (CEDAR) lab under Dr. Joshua Summers. While at Clemson, he received many national awards and was a recipient of the ASME Graduate Teaching Fellowship. His research focuses on developing computational representation and reasoning support for the management complex system design, and is currently implemented in multiple industry practices. Dr. Morkos' research has been published in several journals and conference proceedings around the world. He graduated with his B.S. and M.S in Mechanical Engineering in 2006 and 2008 from Clemson University and has worked on multiple sponsored projects funded by partners such as NASA, Michelin, and BMW. His past work experience include working at the BMW Information Technology Research Center (ITRC) as a Research Associate and Robert Bosch Corporation as a Manufacturing Engineer. Dr. Morkos' research thrust include: design representations, computational reasoning, systems modeling and engineering, engineering education, collaborative design, and data/knowledge management. 


\title{
Process Analysis as a Feedback Tool for Development of Engineering Problem Solving Skills
}

\begin{abstract}
The goal of advancing personalized learning through tailoring instruction to meet students' individual needs requires an analysis of the cognitive processes that lead to discrepancies during learning. This cannot be adequately accomplished using outcome-based scoring methods. The purpose of this research was to test and refine an evidence-based method of assessing students' problem solving processes, and establish a tool that is robust enough to assess problems from a variety of contexts and formats.

The assessment tool was developed using three well-defined story problems of various contexts for first year engineering students enrolled in an introductory course. Process analysis was applied to identify cognitive tasks used in successful solutions and common errors made in students' problem solving attempts. These tasks and errors were mapped to a six-category problem-solving cycle, enabling the evaluation of the problem solving process, identifying underutilization of key tasks and errors committed in each stage of the process.

Results of testing and refinement of the assessment tool are presented in this study. Percent agreement and Cohen's Kappa statistics were calculated to assess inter-rater reliability between instructors using the assessment tool and to assess convergent validity between process analysis using the coding scheme and the modified process analysis using the assessment tool. The major advantage to the assessment tool over traditional grading methods is that it can provide personalized feedback to students about their level of problem-solving proficiency as well as pinpoint skill deficiencies that need attention.
\end{abstract}

\section{Introduction}

One of the directives set forth by the National Academy of Engineers urges educational researchers to develop means of advancing personalized learning through tailoring instruction to meet students' individual needs ${ }^{1}$. The main challenge with providing personalized learning is that there are a vast number of ways that students can err, all of which require different instructional interventions to amend. Identifying individual instructional needs relative to problem solving skills requires a different form of assessment than traditional outcomes-based grading systems; namely, one that examines cognitive processes and discrepancies in solution paths. Process-based analysis examines methods and systems to identify weak points in the process $^{2}$ and can also be used to assess efficiency of processes. While this form of assessment is more labor intensive, the enhanced assessment can uncover skills deficiencies and has the potential for significant improvement in student learning gains.

\section{Research Purpose}

The purpose of this research was to test and refine an evidence-based method of assessing 
students' problem solving processes and establish a tool that is robust enough to be used to assess problem solving proficiency with problems from a variety of contexts and formats. The assessment tool was utilized to evaluate a sample of student work on two newly developed problems with varying problem structures to further establish generalizability beyond the three well-defined problems used in the initial development of the assessment tool. Reliability and validity measures were conducted to determine if the tool was robust enough to be used as a measure of problem solving proficiency.

\section{Development of the assessment tool}

In a study of first year engineering students enrolled in an introductory course focused on building foundational skills, process analysis was applied to identify common tasks, errors and strategies used by students to solve problems ${ }^{3}$. Students were given three well-defined story problems, in which the problem statement and system constraints were clearly communicated to the student ${ }^{4}$. Students recorded their problem solving solutions using Tablet PCs with a custom software called MuseInk which digitally records all ink strokes and erasures, students' audio commentary, and could be subsequently replayed in full to analyze the process ${ }^{5}$. The software allows students to work through problems much as they would with pen and paper, with the added benefit of having electronic access to their work, while researchers are provided with a comprehensive expression of the problem solving attempt from beginning to end, including work that was erased. The digital Ink data was exported to a database for process analysis. The analysis resulted in the establishment of a coding scheme to classify the process of problem solving attempts, which was demonstrated to be reliable and valid for well-defined story problems appropriate for first year engineering students ${ }^{6}$. A subset of these codes were shown to be more frequently present in either successful or unsuccessful solution attempts ${ }^{7}$. Tasks associated with successful solutions and errors associated with unsuccessful solutions were then mapped onto the problem solving process as presented by Pretz, Naples, and Sternberg 8 . Based on the findings of this research, an assessment tool was developed that enables the evaluation of the problem solving process, pinpointing underutilization of key tasks that have been linked to successful problem solutions as well as identifying errors committed in each segment of the process. The complete assessment consisted of eight stages and a measure of solution accuracy.

Next, the assessment tool was modified into a form that could be used to assess problem solutions in the absence of a complete recording of the problem solving process. This ensures a tool that is more generalizable to the target user group of instructors and education researchers who would not necessarily have access to a complete digital recording of student problem solving attempts. To accomplish this, the first two of Pretz et al.'s stages were combined for simplicity, and two stages were eliminated due to the inability to evaluate them without analyzing a complete digital recording of a student's solution. While this modified process analysis lacks the ability to assess some skills that were found to be highly correlated to problem solving success (namely those associated with erasures), it provides a more time efficient method that is more feasible to implement with current classroom resources.

The resulting abbreviated process analysis assessment tool classifies problem solutions based on the following categories: 1) identify problem and system constraints, 2) represent the problem, 3) 
organize knowledge about the problem, 4) allocate resources for solving the problem, and 5) evaluate the solution. A sixth category was added for final solution accuracy. The assessment tool can be found in Appendix A. This six-category instrument ranks student performances based on level of proficiency exhibited for each skill (acceptable/inadequate/missing) and identifies the presence or absence of errors. These values are tallied for an overall score that reflects level of problem-solving proficiency.

The scoring system was designed to emphasize the importance of building a strong foundational understanding of the problem solving process itself and reduce the students' preoccupation with simply obtaining the correct answer. While there is certainly a benefit in knowing whether the obtained answer is correct or incorrect, the true power of process analysis lies in being able to provide feedback on the root cause of incorrect solutions so that students may become more aware of performance deficiencies. Because each stage of the problem solving process is considered to be equally important, the categories were assigned the same point value, with partial credit awarded for processes that were attempted but were inadequately executed. The accuracy of the final solution is only one of the categories and is also weighted equivalently with each stage.

The original assessment tool was given to a focus group of 4 engineering and science education graduate students, who provided feedback and directed the structure and content of a user guide. As a result of the focus group, the assessment tool was refined, and the user guide was written to include definitions and examples of each task and error, and directions on how to score student work. The user guide is presented in Appendix B.

\section{Data Collection Methods}

In Spring 2012, six focus groups were conducted comprised of first year engineering students who had passed their first semester introductory engineering course. Fifty-five students participated, and were provided with tablet computers with the MuseInk software installed to complete one of two original, somewhat ill-defined story problems ${ }^{4}$ related to the engineering grand challenge of providing access to clean water. One of the problems focused on water usage in an Indian village and asked students to determine if there was enough water remaining in a watershed after rainfall, evaporation, and other water losses were taken into account to accommodate the villagers' current usage ("watershed" problem). The second problem focused on water storage in a Haitian village, and students were asked to find the optimal design for a cistern given dimension constraints and costs of building materials ("cistern" problem). Both problems were based on authentic projects being conducted by student research teams at Clemson University. Neither of these problems required math skills above algebra to solve.

Students were given thirty minutes to work their problem. They were then instructed to go back and explain what they did and what they were thinking while working the problem through use of the MuseInk commentary capability. These explanations were also recorded, but were not used in this study. Because the assessment tool is meant for instructors to provide feedback to their students on their written work, only the students' final written work was scored using the assessment tool. 


\section{Data Analysis Methods}

Two instructors from the first year engineering program were asked to use the problem solving process assessment tool to evaluate a sample of student work. One of the instructors was not involved in any way with the research involved in developing the tool, nor was she involved in the development of the problems under investigation, or the data collection process. The other instructor was a member of the research team who was involved in the development of the initial coding scheme and assessment tool, but did not participate in the focus group that refined the assessment tool and user guide. For initial testing, a subset of six of the 56 problem solutions were randomly selected (one student from each focus group, three each of the two problems). The instructors were provided with a training session on how to use the assessment tool before grading the six problems independently. This training involved reviewing the assessment tool, user guide, and problem solutions, scoring two problems together with a different member of the research team, and discussing discrepancies as they arose. Problem solutions were written by members of the research team, and were organized to align with the assessment tool categories, with specific items identified wherever possible.

The six students' problem solutions were also coded using the complete process analysis method, coding the digital recording of the process from beginning to end, including erasures. This full coding scheme was applied by an "expert" from the research team, who was also one of the two instructors who tested the assessment tool (Instructor 2). Coding was completed shortly after the data was collected, approximately 6 months before this instructor scored problems with the assessment tool.

Two forms of statistical analysis were conducted on the results of these assessments. First, percent agreement and Cohen's Kappa were calculated to evaluate the level of inter-rater reliability between the two instructors using the process analysis assessment tool. This serves as an evidence-based estimate of how consistent users of the tool would be. Next, comparisons were made between methods, comparing the complete process analysis (coding the entire solution process) and the assessment tool (scoring the final solution documentation) to establish construct validity of the new method. It is to be expected that there should be some variability between these two methods, as the assessment tool rates solutions on only a subset of possible codes, and is based on a reduced amount of data related to the problem solution. This serves as an estimate of how consistent the two assessment methods are in terms of conclusions about student problem solving proficiency. Strength of agreement was evaluated using Gwet's classifications which describe Kappa values of 0.00-0.20 as being "slight", $0.21-0.40$ as being "fair", $0.41-0.60$ as being "moderate", $0.61-0.80$ as being "substantial", and 0.81-1.00 as being "almost perfect"?.

\section{Results}

Inter-rater reliability was evaluated by comparing the scored assessment tools from the two instructors for the six student solutions. Each task and error was treated as its own item. The assessment tool has a total of 43 items. The results from comparing all items for all six problems are shown in Table 1 . There was $85.66 \%$ agreement between the two instructors which is almost 
perfect, but Cohen's Kappa was 0.60, indicating that some of the agreement is likely due to chance. When separating the two different problems, the results are better for the cistern problem, with a Kappa of 0.65 , indicating a "substantial" strength of agreement.

Table 1: Inter-rater reliability for scoring results from two instructors

\begin{tabular}{|l|c|c|c|}
\hline Problems & Percent Agreement & Cohen's Kappa & Strength of agreement \\
\hline All Problems & 85.66 & 0.60 & moderate \\
\hline Cistern Problem & 86.82 & 0.65 & substantial \\
\hline Watershed Problem & 84.50 & 0.54 & moderate \\
\hline
\end{tabular}

To test for convergent validity, the results from the assessment tool were compared to results from the complete process analysis (full coding scheme). Only the tasks and errors that the coding scheme and assessment tool have in common were used for comparison, which was a total of 35 items. The results are shown in Table 2. The average Kappa for the two methods was 0.56 , indicating only moderate strength of agreement in spite of the fact that one of the instructors (Instructor 2) was also the "expert" applying the full coding scheme. This indicates that there are variations between methods.

Table 2: Validity test: comparison of results from assessment tool and coding scheme

\begin{tabular}{|l|l|c|c|c|}
\hline $\begin{array}{l}\text { Coding Results } \\
\text { Comparison }\end{array}$ & Problem & $\begin{array}{c}\text { Percent } \\
\text { Agreement }\end{array}$ & $\begin{array}{c}\text { Cohen's } \\
\text { Kappa }\end{array}$ & $\begin{array}{c}\text { Strength of } \\
\text { agreement }\end{array}$ \\
\hline $\begin{array}{l}\text { Instructor 1Assessment } \\
\text { Tool vs. Full Coding } \\
\text { Scheme }\end{array}$ & All Problems & 76.10 & 0.43 & moderate \\
\cline { 2 - 5 } & Cistern Problem & 76.70 & 0.48 & moderate \\
\cline { 2 - 5 } & $\begin{array}{l}\text { Watershed } \\
\text { Problem }\end{array}$ & 75.50 & 0.35 & fair \\
\hline $\begin{array}{l}\text { Instructor 2 Assessment } \\
\text { Tool vs. Full Coding } \\
\text { Scheme }\end{array}$ & All Problems & 86.83 & 0.68 & substantial \\
\cline { 2 - 5 } & Cistern Problem & 88.35 & 0.74 & substantial \\
\cline { 2 - 5 } & $\begin{array}{l}\text { Watershed } \\
\text { Problem }\end{array}$ & 84.31 & 0.62 & substantial \\
\hline
\end{tabular}

In general, the tests for reliability and validity of results yielded higher agreement for the cistern problem. One possible explanation is that this was a more difficult problem. Because it was more difficult and students were given a time limit, many of them didn't finish. Nine of the forty-three items on the assessment tool require a final solution. When a student clearly doesn't get an answer, none of those nine items are checked and the last two categories each result in a score of zero. The instructors would always agree on this.

\section{Discussion}

Results indicate that further testing is needed to demonstrate that scores using the assessment tool are both reliable and valid. The main concern and likely cause for discrepancies in tasks and errors checked is a difference in interpretation. For example, when instructors check if students identified the system constraints and if they communicated all assumptions, the difference between a constraint and an assumption may not be clearly understood. It was observed that 
when an error was present in a student's solution, instructors were not clear which type of error to code it as. This will be addressed through further refinement of the assessment tool and user guide in response to continuing data analysis.

Students were limited to only 30 minutes when completing these problems on tablets. Very few students finished the problem due to the time constraint. It is difficult to assess a student's problem solving processes when they were unable to finish the process; however, it was helpful to see that tasks could be identified within incomplete work. Thus the assessment tool can provide valuable feedback to students who get "stuck" and/or do not complete the problem. In addition to these focus group participants, 35 students worked the problems on paper (17 watershed, 18 cistern) without a time limit, and thus a greater percentage completed the problem. These problems will be used for further inter-rater reliability testing, to examine if results improve when the raters are scoring complete problem solutions.

One limitation of this study is that only six sample problems were included for testing the reliability and validity of the assessment tool results. This will be addressed through further testing of the tool (scoring all students' solutions to the two grand challenge problems). The assessment tool will be refined as needed in response to the results of these tests. Another limitation is that the complete process analysis and the assessment tool were applied to the six problems by the same person. In future data analysis, only instructors who are not members of the research team will be asked to score the student solutions.

\section{Conclusions}

There is a need for an assessment tool that can be used to provide feedback to students on a variety of first-year engineering problems in terms of their problem solving proficiency. From our research into students' problem solving processes, we have developed an evidence-based assessment tool that is robust enough for use on problems from a variety of contexts and formats. The tests for reliability and validity of data from our assessment tool resulted in Cohen Kappa values of 0.60 and 0.56 , respectively.

The major advantage to this assessment tool over traditional grading methods is that it can be applied as a personalized feedback system to inform students of their level of proficiency as well as pinpoint skill deficiencies that need attention. This information could then be used by instructors to direct students to resources and/or to design instructional interventions for overcoming these deficiencies. Additionally, researchers can use this assessment tool to investigate the effectiveness of various pedagogical interventions in terms of improving problem solving performance and pinpointing what skill(s) are most affected. The assessment tool has been evaluated in terms of reliability and validity for use with different problems designed for first year engineering students, specifically testing its use with problem statements that have modified structures and that address contexts that are new to students. Although results of these tests are acceptable, further refinements and testing of the assessment tool are being conducted to ensure that it is robust enough for instructional use with a wide variety of problem types and contexts. 


\section{Acknowledgements}

The authors wish to thank Dr. Pat Gerard for his assistance with the statistical analysis, and the NSF for funding this project (EEC award \# EEC - 0935163). We also wish to acknowledge Zahra Baratian-Ghorghi, Courtney Faber, Eliza Gallagher, Allison Godwin, Adam Kirn, Catherine McGough, and Narcrisha Norman for their assistance with the development of the assessment tool.

\section{References}

1. Perry W, Broers A, El-Baz F, Harris W, Healy B, Hillis WD. Grand Challenges for Engineering. In: National Academy of Engineering. Washington, DC; 2008.

2. Scheer A-W, Ferri, Abolhassan F, Jost W, Kirchmer M. Business process change management: ARIS in practice. Springer Publishing Company, Incorporated; 2003.

3. Grigg SJ. A process analysis of engineering problem solving and assessment of problem solving skills. Industrial Engineer. 2012;(December):p. 251.

4. Jonassen DH. Learning to Solve Problems. San Francisco, CA: Pfeiffer; 2004.

5. Bowman D, Benson L. MuseInk: Seeing and hearing a freshman engineering student think. In: 2010 ASEE Annual Conference Proceedings.; 2010.

6. Grigg S, Benson L. A coding scheme for analyzing problem solving processes of first year engineering students. Journal of Engineering Education. 2013:under review.

7. Grigg SJ, Benson LC. Effects of Student Strategies on Successful Problem Solving. In: ASEE Annual Conference. San Antonio, TX; 2012.

8. Pretz JE, Naples AJ, Sternerg RJ. Recognizing, Defining, and Representing Problems. In: The Psychology of Problem Solving.; 2003:3-30.

9. Gwet KL. Handbook of inter-rater reliability: The definitive guide to measuring the extenet of agreement among multiple raters. Advanced Analytics Press; 2012. 


\section{Appendix A - The Assessment Tool}

\begin{tabular}{|c|c|c|c|c|c|c|c|}
\hline & Grader: & & $\begin{array}{l}\text { Student } \\
\text { ID: }\end{array}$ & & & & \\
\hline & Problem & & & evel of Completio & & Frun(c) Committod & Process \\
\hline & Solving & Explicit Tasks & Missing & Inadequate & Acceptable & 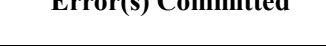 & Score \\
\hline & $\begin{array}{l}\text { Process/ } \\
\text { Category }\end{array}$ & & 0 points & 1 point & 2 points & (-1 point) & $\begin{array}{c}(0 \text { to } 2 \\
\text { each) }\end{array}$ \\
\hline & $\begin{array}{l}\text { Identify } \\
\text { Problem and } \\
\text { System } \\
\text { Constraints }\end{array}$ & $\begin{array}{l}\text { Identified unknown } \\
\square \text { Restated problem } \\
\square \text { Identified system } \\
\text { constraints } \\
\square \text { Communicated } \\
\text { assumptions }\end{array}$ & $\begin{array}{l}\text { Did not explicitly } \\
\text { identify or define } \\
\text { the } \\
\text { problem/system }\end{array}$ & $\begin{array}{l}\text { Completed some } \\
\text { problem/system } \\
\text { definition tasks }\end{array}$ & $\begin{array}{l}\text { Clearly identified } \\
\text { and defined the } \\
\text { problem/system }\end{array}$ & $\begin{array}{l}\square \text { Incorrect unknown } \\
\square \text { Incorrect assumption } \\
\square \text { Ignored or incorrect } \\
\text { problem constraints }\end{array}$ & \\
\hline 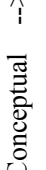 & $\begin{array}{l}\text { Represent } \\
\text { the Problem }\end{array}$ & $\begin{array}{l}\square \text { Drew a visual } \\
\text { representation } \\
\square \text { Relate } \\
\text { variables/values }\end{array}$ & $\begin{array}{l}\text { No } \\
\text { representation } \\
\text { drawn, no } \\
\text { relationships } \\
\text { indicated } \\
\end{array}$ & $\begin{array}{l}\text { Drew a } \\
\text { representation or } \\
\text { related variables, } \\
\text { but not both }\end{array}$ & $\begin{array}{c}\text { Drew a } \\
\text { representation } \\
\text { and indicated } \\
\text { variable } \\
\text { relationships } \\
\end{array}$ & $\begin{array}{l}\square \text { Incorrect representation } \\
\square \text { Incorrect relate variables }\end{array}$ & \\
\hline & $\begin{array}{l}\text { Organize } \\
\text { Knowledge }\end{array}$ & $\begin{array}{l}\text { Identified known } \\
\text { values } \\
\square \text { Identified } \\
\text { equation(s) } \\
\square \text { Identified } \\
\text { conversion factor } \\
\end{array}$ & $\begin{array}{l}\text { Did not explicitly } \\
\text { organize } \\
\text { information } \\
\text { about the } \\
\text { problem }\end{array}$ & $\begin{array}{l}\text { Completed some } \\
\text { information } \\
\text { organization } \\
\text { tasks }\end{array}$ & $\begin{array}{l}\text { Fully organized } \\
\text { information } \\
\text { needed to solve } \\
\text { the problem }\end{array}$ & $\begin{array}{l}\square \text { Incorrect known values } \\
\square \text { Misused governing } \\
\text { equation } \\
\square \text { Incorrect conversion } \\
\text { factor }\end{array}$ & \\
\hline 苞 & $\begin{array}{l}\text { Allocate } \\
\text { Resources } \\
\text { (Execution) }\end{array}$ & $\begin{array}{l}\square \text { Manipulated } \\
\text { equation } \\
\square \text { Derived units } \\
\square \text { Used conversion } \\
\text { factor } \\
\square \text { Documented math }\end{array}$ & No work shown & $\begin{array}{c}\text { Partially } \\
\text { documented } \\
\text { execution tasks } \\
\text { (Work showed } \\
\text { some evidence of } \\
\text { relevant tasks) }\end{array}$ & $\begin{array}{l}\text { Fully } \\
\text { documented } \\
\text { execution tasks } \\
\text { (Work showed } \\
\text { evidence of } \\
\text { relevant tasks) }\end{array}$ & $\begin{array}{l}\square \text { Incorrectly manipulated } \\
\text { equation } \\
\square \text { Incorrect calculation } \\
\square \text { Incorrect unit derivation } \\
\square \text { Inconsistent transcription } \\
\square \text { Inconsistent units } \\
\square \text { Incorrect unit assignment } \\
\square \text { Missing units throughout } \\
\square \text { Used irrelevant } \\
\text { information } \\
\square \text { Other }\end{array}$ & \\
\hline & $\begin{array}{l}\text { Evaluate the } \\
\text { Solution }\end{array}$ & $\begin{array}{l}\square \text { Checked accuracy } \\
\square \text { Indicated final } \\
\text { answer } \\
\square \text { Justified final } \\
\text { answer }\end{array}$ & $\begin{array}{l}\text { Did not evaluate } \\
\text { solution }\end{array}$ & $\begin{array}{c}\text { Explicitly } \\
\text { evaluated the } \\
\text { solution, but } \\
\text { flawed in some } \\
\text { way }\end{array}$ & $\begin{array}{l}\text { Adequately } \\
\text { evaluated the } \\
\text { solution }\end{array}$ & $\begin{array}{l}\square \text { Incorrectly manipulated } \\
\text { equation } \\
\square \text { Incorrect calculation } \\
\square \text { Incorrect unit derivation } \\
\square \text { Inadequate reasoning }\end{array}$ & \\
\hline & $\begin{array}{c}\text { Final } \\
\text { Solution } \\
\text { Accuracy }\end{array}$ & & Missing Answer & $\begin{array}{l}\text { Incomplete } \\
\text { Answer }\end{array}$ & $\begin{array}{l}\text { Complete } \\
\text { Answer }\end{array}$ & $\begin{array}{l}\square \text { Missing units } \\
\square \text { Incorrect units } \\
\square \text { Incorrect value } \\
\square \text { Did not answer the } \\
\text { question }\end{array}$ & \\
\hline
\end{tabular}




\section{Appendix B}

\section{Problem Solving Process Assessment User Guide: Overview and General Scoring Instructions}

Overview: This assessment provides feedback on written problem solutions in terms of proficiency level on key stages linked to successful problem solving, and errors identified within each stage. The intention is to provide feedback to students about their performance of the problem solving process, not just the outcome (i.e. final answer). It measures problem solving performance based on the tasks explicitly completed in problem solutions, assessing how thoroughly students complete each stage of the problem solving process, as well as the quality of their work within each stage. The final category rates the completeness and quality of the solution outcome. Descriptions of each process measure and errors are provided on the following two pages.

\section{How to score student work:}

1. Assess student's work line by line, from beginning to end, checking tasks under "Explicit Tasks Performed" (partially or completely, regardless of quality of the work). Tasks not explicitly performed are not checked.

2. Rate how well the student completed each problem solving stage under "Level of Completion" to indicate quality and proficiency; descriptions in each box guide ratings. Evaluate only work completed, even if solution is incomplete; completion is assessed in "Final Solution Accuracy." If a task is not required for the solution, points should not be deducted for the missing task. For example, under Identify Problem and System Constraints, if no assumptions need to be made to solve the problem, no points are subtracted for missing this task. An example of how work within this stage might be scored:

Level 0: Missing - no tasks related to problem or system identification were attempted

Level 1: Inadequate - all unknown values but only some required constraints are identified

Level 2: Acceptable - all required tasks are completed

3. Identify "Error(s) Committed". If a task is not checked as being performed, no further points are deducted for error(s) related to that task. Likewise, no points should be deducted for errors within a stage if the "Level of Completion" for that stage was rated as "Missing". All incorrect solutions will have at least one error, and possibly multiple errors, identified.

4. Calculate "Process Score" for each process/category; scores should be between 0 and 2 . Each process containing at least one error loses 1 point; do not deduct multiple points for multiple errors within the same process. Calculate "Total Score" by summing Process Scores, for overall problem solving proficiency; total possible points $=12$.

Note: The following two pages provide comprehensive definitions of each category of processes and errors. These two pages can be printed front-to-back and serve as a quick-reference guide when using the problem solving process assessment tool.

\section{Reference:}

Grigg, S., Benson, L., Van Dyken, J., and Morkos, B. (2013) Process Analysis as a Feedback Tool for Development of Engineering Problem Solving Skills. Accepted for presentation at the 2013 ASEE Annual Conference, June 23-26, 2013, Atlanta, GA. 


\section{Problem Solving Process Assessment User Guide: Problem Solving Process Stages / Categories}

\begin{tabular}{|c|c|c|c|c|}
\hline & $\begin{array}{c}\text { Problem Solving Process / } \\
\text { Category }\end{array}$ & $\begin{array}{l}\text { Explicit tasks } \\
\text { performed }\end{array}$ & Description & Example \\
\hline \multirow{9}{*}{ 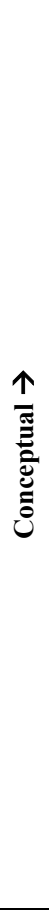 } & \multirow{4}{*}{$\begin{array}{l}\text { Identify Problem and System } \\
\text { Constraints Student forms an } \\
\text { understanding of the problem } \\
\text { and sets bounds on what is } \\
\text { under investigation, including } \\
\text { what is ultimately being solved } \\
\text { for, and what restrictions they } \\
\text { are given. }\end{array}$} & Identified unknown & $\begin{array}{l}\text { Explicitly identifies the variable to } \\
\text { solve for in the problem }\end{array}$ & $\begin{array}{l}\text { Writes: } A=\text { ? } \\
\text { Writes: "solving for } A \text { ", "want } A \text { ", "find } \\
A \text { ", etc. }\end{array}$ \\
\hline & & Restated problem & $\begin{array}{l}\text { Re-writes or summarizes the } \\
\text { problem statement using phrases or } \\
\text { sentences }\end{array}$ & $\begin{array}{l}\text { "Find an equivalent circuit that will } \\
\text { yield the same resistance as the one } \\
\text { given" }\end{array}$ \\
\hline & & $\begin{array}{l}\text { Identified system } \\
\text { constraints }\end{array}$ & $\begin{array}{l}\text { Explicit statement of constraint as } \\
\text { given in the problem or by instructor }\end{array}$ & $\begin{array}{l}\text { "Can only use one of each type of } \\
\text { resistor, but do not have to use them } \\
\text { all" }\end{array}$ \\
\hline & & $\begin{array}{l}\text { Communicated } \\
\text { assumptions }\end{array}$ & $\begin{array}{l}\text { Explicit statement of assumption } \\
\text { made by student, not identified } \\
\text { within problem statement }\end{array}$ & $\begin{array}{l}\text { "Assume we have an infinite supply of } \\
\text { resistors" }\end{array}$ \\
\hline & \multirow{2}{*}{$\begin{array}{l}\text { Represent the Problem } \\
\text { Student conceptualizes the } \\
\text { system under investigation; } \\
\text { utilizes visual representations } \\
\text { (charts, sketches, or diagrams) } \\
\text { to help understand problem } \\
\text { and relationships between } \\
\text { variables. } \\
\end{array}$} & $\begin{array}{l}\text { Drew a visual } \\
\text { representation }\end{array}$ & $\begin{array}{l}\text { Draws a visual representation of the } \\
\text { information }\end{array}$ & $\begin{array}{l}\text { Chart, sketch, flow diagram, schematic, } \\
\text { Venn diagram, etc. }\end{array}$ \\
\hline & & $\begin{array}{l}\text { Relate } \\
\text { variables/values }\end{array}$ & $\begin{array}{l}\text { Assigns/inserts values to a diagram, } \\
\text { assigns relationships in the system, } \\
\text { and/or shows connections }\end{array}$ & $\begin{array}{l}\text { Adds } 20 \mathrm{ft} \text { to indicate the length of a } \\
\text { structure, or } \\
l=2 \cdot w \text { to indicate relationship; adds } \\
\text { arrows between values to show flow or } \\
\text { relationships }\end{array}$ \\
\hline & \multirow{3}{*}{$\begin{array}{l}\text { Organize Knowledge (shift } \\
\text { from conceptual to analytical } \\
\text { evaluation) Student gathers } \\
\text { information necessary to solve } \\
\text { the problem, including relevant } \\
\text { conversion factors or values of } \\
\text { standard constants. (all=2; } \\
\text { some }=1 \text { ) }\end{array}$} & $\begin{array}{l}\text { Identified known } \\
\text { values }\end{array}$ & $\begin{array}{l}\text { Defines variable(s) using } \\
\text { information given in the problem }\end{array}$ & $l=20 \mathrm{ft}$ \\
\hline & & $\begin{array}{l}\text { Identified } \\
\text { equation(s) }\end{array}$ & $\begin{array}{l}\text { Equation(s) explicitly stated without } \\
\text { numbers inserted }\end{array}$ & $A=l \cdot w$ \\
\hline & & $\begin{array}{l}\text { Identified } \\
\text { conversion factor }\end{array}$ & $\begin{array}{l}\text { Writes numerical value of } \\
\text { conversion factor }\end{array}$ & Writes $1 \mathrm{~N}=0.225 \mathrm{lb} b_{f}$ \\
\hline \multirow{7}{*}{ 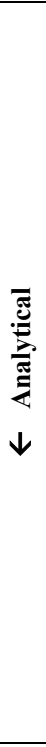 } & \multirow{4}{*}{$\begin{array}{l}\text { Allocate Resources } \\
\text { (Execution) } \\
\text { Main stage of documented } \\
\text { work; includes tasks related to } \\
\text { transforming data into } \\
\text { information; mathematical } \\
\text { calculations, including } \\
\text { converting between unit } \\
\text { systems or other forms of data } \\
\text { translation. Not all tasks } \\
\text { associated with this stage are } \\
\text { relevant to every problem; only } \\
\text { relevant tasks should be } \\
\text { evaluated. }\end{array}$} & $\begin{array}{l}\text { Manipulated } \\
\text { equation }\end{array}$ & $\begin{array}{l}\text { Solves an explicitly written equation } \\
\text { for another variable }\end{array}$ & Writes $A=l \cdot w$ and then writes $l=\frac{A}{w}$ \\
\hline & & Derived units & $\begin{array}{l}\text { Writes or uses a multi-step } \\
\text { conversion to change the data from } \\
\text { one unit to an equivalent unit }\end{array}$ & $\begin{array}{l}\text { Converts from Pascals to } \mathrm{kg} / \mathrm{ms}^{2} \text { by } \\
\text { using } P a=N / \mathrm{m}^{2} \text { and } N=\mathrm{kg} \cdot \mathrm{m} / \mathrm{s}^{2}\end{array}$ \\
\hline & & $\begin{array}{l}\text { Used conversion } \\
\text { factor }\end{array}$ & $\begin{array}{l}\text { Uses a single-step equation to } \\
\text { change date from one unit to a } \\
\text { different unit }\end{array}$ & $\begin{array}{l}\text { Converts } 4 \mathrm{ft} \text { to } 48 \mathrm{in} \text { with or without } \\
\text { writing } 1 \mathrm{ft}=12 \mathrm{in}\end{array}$ \\
\hline & & Documented math & $\begin{array}{l}\text { Writes the numerical result from } \\
\text { performing a mathematical operation } \\
\text { and/or algebraic activity }\end{array}$ & Writes 40 as a result of $15+25$ \\
\hline & \multirow{3}{*}{$\begin{array}{l}\text { Evaluate the Solution Student } \\
\text { evaluates work in terms of } \\
\text { accuracy, level of } \\
\text { understanding, or satisfying the } \\
\text { goal of the problem. For } \\
\text { multiple part and/or incomplete } \\
\text { solutions, student checks and } \\
\text { justifies intermediate answers. }\end{array}$} & Checked accuracy & $\begin{array}{l}\text { Plugs answer back into equation to } \\
\text { check for errors }\end{array}$ & $\begin{array}{l}\text { Math off to the side, indicated with } \sqrt{ } \text { or } \\
-0 \text { or other indicator of } \\
\text { acknowledgement as accurate }\end{array}$ \\
\hline & & $\begin{array}{l}\text { Indicated final } \\
\text { answer }\end{array}$ & Boxes, underlines or circles answer & $\underline{A=200 \mathrm{ft}^{2}}$ \\
\hline & & $\begin{array}{l}\text { Justified final } \\
\text { answer }\end{array}$ & $\begin{array}{l}\text { Describes in words why their answer } \\
\text { is correct (not typically included } \\
\text { unless explicitly required in } \\
\text { problem) }\end{array}$ & $\begin{array}{l}\text { "Because the outflow is greater than the } \\
\text { inflow, there will be a deficit." }\end{array}$ \\
\hline & \multirow{2}{*}{$\begin{array}{l}\text { Final Solution Accuracy } \\
\text { Student fulfills goal of problem } \\
\text { (i.e. correct answer with } \\
\text { correct units). }\end{array}$} & Incomplete answer & \multicolumn{2}{|c|}{$\begin{array}{l}\text { Correct or incorrect partial solution, or solution(s) to only part(s) of multi-part } \\
\text { problem }\end{array}$} \\
\hline & & Complete answer & \multicolumn{2}{|c|}{$\begin{array}{l}\text { Correct or incorrect complete solution; solutions provided for all parts of multi- } \\
\text { part problem }\end{array}$} \\
\hline
\end{tabular}




\section{Problem Solving Process Assessment User Guide: Errors Committed}

\begin{tabular}{|c|c|c|c|}
\hline Category & Error(s) Committed & Description & Examples \\
\hline \multirow{3}{*}{$\begin{array}{l}\text { Identify } \\
\text { Problem and } \\
\text { System } \\
\text { Constraints }\end{array}$} & Incorrect unknown & Solves for the wrong variable & $\begin{array}{l}\text { Solves for perimeter when the problem asks for } \\
\text { area }\end{array}$ \\
\hline & Incorrect assumptions & $\begin{array}{l}\text { Uses/identifies wrong information from } \\
\text { student's own resources, or places constraints } \\
\text { on system not given in problem }\end{array}$ & $\begin{array}{l}\text { Does not account for frictional force in the } \\
\text { model (assumes effects of friction are } \\
\text { negligible) }\end{array}$ \\
\hline & $\begin{array}{l}\text { Ignored or incorrect } \\
\text { constraints }\end{array}$ & Misuses problem information as constraints & $\begin{array}{l}\text { Problem says use only one of each type of } \\
\text { resistor, but student uses two of one type in } \\
\text { solution }\end{array}$ \\
\hline \multirow[b]{2}{*}{$\begin{array}{l}\text { Represent } \\
\text { Problem }\end{array}$} & Incorrect representation & $\begin{array}{l}\text { Misrepresents underlying concepts or the } \\
\text { system of the problem. }\end{array}$ & $\begin{array}{l}\text { Draws a diagram of flow in and out, but neglects } \\
\text { one or more branch }\end{array}$ \\
\hline & $\begin{array}{l}\text { Incorrectly relates } \\
\text { variables }\end{array}$ & $\begin{array}{l}\text { Incorrect association between variables; adds } \\
\text { wrong value to a diagram; implicitly relates } \\
\text { wrong value to a variable in an equation; } \\
\text { incorrectly labels a variable in a diagram }\end{array}$ & $\begin{array}{l}\text { - Labels } 10 \mathrm{ft} \text { for length on diagram when it } \\
\text { should be } 20 \mathrm{ft} \\
\text { - Writes } w=2 \cdot l \text { when it should be } l=2 \cdot w \text {. }\end{array}$ \\
\hline \multirow{2}{*}{$\begin{array}{l}\text { Organize } \\
\text { Knowledge/ } \\
\text { Evaluate the } \\
\text { Solution }\end{array}$} & Incorrect known values & $\begin{array}{l}\text { Inserts a wrong value for a variable in an } \\
\text { equation }\end{array}$ & $\begin{array}{l}\text { Replaces } l \text { with } 10 \mathrm{ft} \text { when } l \text { was defined as } \\
20 \mathrm{ft} \text { in the problem. }\end{array}$ \\
\hline & $\begin{array}{l}\text { Incorrect conversion } \\
\text { factor }\end{array}$ & $\begin{array}{l}\text { Utilizes an incorrect multiplier and/or assigns } \\
\text { incorrect units when doing a unit conversion }\end{array}$ & $\begin{array}{l}\text { - Converts } \mathrm{km}^{2} \text { to } \mathrm{m}^{2} \text { with } \mathrm{km}^{2}=1000 \mathrm{~m}^{2} \\
\text { or } \mathrm{km}^{2}=1000 \mathrm{~m} \\
\left(\text { should be } \mathrm{km}^{2}=1,000,000 \mathrm{~m}^{2} \text { ) }\right.\end{array}$ \\
\hline \multirow{8}{*}{$\begin{array}{l}\text { Allocate } \\
\text { Resources } \\
\text { (Execution) }\end{array}$} & $\begin{array}{l}\text { Incorrectly manipulated } \\
\text { equation }\end{array}$ & $\begin{array}{l}\text { Makes an algebraic mistake in an identified } \\
\text { equation }\end{array}$ & Writes $l=\frac{w}{A}$ after explicitly writing $A=l \cdot w$ \\
\hline & Incorrect calculation & $\begin{array}{l}\text { Plugs wrong numbers and/or mathematical } \\
\text { operators in calculator }\end{array}$ & $\begin{array}{l}\text { Writes } A=2000 \mathrm{ft}^{2} \text { after writing } A=20 \mathrm{ft} \cdot \\
10 \mathrm{ft} \text { (adds an extra } 0)\end{array}$ \\
\hline & Incorrect unit derivation & $\begin{array}{l}\text { Calculates wrong units in a single or multi- } \\
\text { step conversion; incorrect dimensional } \\
\text { analysis }\end{array}$ & $\begin{array}{l}\text { Converts Pascals to } \mathrm{kg} / \mathrm{ms} \text { with } P a=N / \mathrm{m}^{2} \\
\text { and } N=\mathrm{kg} \cdot \mathrm{m} / \mathrm{s} \text { (should be } N=\mathrm{kg} \cdot \mathrm{m} / \mathrm{s}^{2} \text {; } \\
1 \text { Pascal }=\mathrm{kg} / \mathrm{ms}^{2} \text { ) }\end{array}$ \\
\hline & Inconsistent transcription & $\begin{array}{l}\text { Incorrectly copies information from one place } \\
\text { to another }\end{array}$ & $\begin{array}{l}\text { Initially writes } A=20 \cdot w, \text { but later writes } \\
A=2 \cdot w\end{array}$ \\
\hline & Inconsistent units & Mismatches units in an equation & $\begin{array}{l}3 P a * 4 L=7 a t m * V \text { (mixed pressure units in } \\
\text { Boyle's Law equation) }\end{array}$ \\
\hline & Incorrect unit assignment & $\begin{array}{l}\text { Arbitrarily and/or incorrectly assigns units to } \\
\text { a value with no other associated work or unit } \\
\text { derivation }\end{array}$ & $A=200 \mathrm{in}^{2}$ instead of $f t^{2}$ \\
\hline & Missing units throughout & $\begin{array}{l}\text { Does not use units (or uses few of them) in } \\
\text { calculations }\end{array}$ & $\begin{array}{l}\text { Only puts units on their final answer; has units } \\
\text { every few steps }\end{array}$ \\
\hline & $\begin{array}{l}\text { Used irrelevant } \\
\text { information }\end{array}$ & $\begin{array}{l}\text { Uses values not given in problem and/or not } \\
\text { needed }\end{array}$ & $\begin{array}{l}\text { Student calculates and tries to use perimeter to } \\
\text { find area }\end{array}$ \\
\hline \multirow{2}{*}{$\begin{array}{l}\text { Evaluate the } \\
\text { Solution }\end{array}$} & $\begin{array}{l}\text { Incorrectly manipulated } \\
\text { Resources", but errors of }\end{array}$ & $\begin{array}{l}\text { ation, Incorrect calculation, Incorrect unit deriy } \\
\text { when student checks work or justifies answer( }\end{array}$ & on - Same definitions as above in "Allocate \\
\hline & Inadequate reasoning & $\begin{array}{l}\text { Justifies answer, but with limited or incorrect } \\
\text { supporting information }\end{array}$ & $\begin{array}{l}\text { "Efficiency is correct because it's between } 0 \text { and } \\
1 \text { " }\end{array}$ \\
\hline \multirow{2}{*}{$\begin{array}{l}\text { Final Solution } \\
\text { Accuracy }\end{array}$} & Missing/Incorrect units & Answer has either no units or incorrect units & $\begin{array}{l}\text { Only value given or gave answer in minutes } \\
\text { when seconds was desired }\end{array}$ \\
\hline & Incorrect value & Wrong answer & $\begin{array}{l}\text { Student gives anything other than the correct } \\
\text { numerical answer }\end{array}$ \\
\hline
\end{tabular}

